\title{
EFL Students' Perception of Distance Learning Practice in a Vocabulary Class
}

\author{
Ribeh Najib Muhammad \\ Universitas Muhammadiyah Gresik \\ ribeh@umg.ac.id
}

\begin{abstract}
The perception of English as a Foreign Language (EFL) students toward the significance of distance learning practice in EFL teaching at university is essential to provide suggestions for enhancing distance learning practice in the context of EFL teaching. Therefore, the purpose of this study was to investigate students' perception towards distance learning practice at University of Muhammadiyah Gresik, especially in Words in Contexts class as the main course for learning vocabularies. Therefore, this study explored several aspects that needed in the implementation of distance learning practice. The subjects of this study were 34 first semester students of English education department who had applied distance learning practice. Questionnaire was used as research instrument to collect data from the respondents who had been selected. In addition, interview was also conducted to confirm the result of questionnaire. After the data were collected, they were analyzed using quantitative and qualitative analysis method. The finding indicated that students had average perception towards the implementation of distance learning practice, since distance learning practice provided advantages for their learning process. However, there were setbacks and problems such as students' participation, internet connectivity, and material clarity that needed to be solved in order to improve the quality of distance learning practice.
\end{abstract}

Keywords: Students'Perception, Distance Learning Practice

\begin{abstract}
Abstrak
Persepsi siswa English as a Foreign Language (EFL) terhadap pentingnya praktik pembelajaran jarak jauh dalam pengajaran EFL di universitas sangat penting untuk memberikan saran dalam peningkatan praktik pembelajaran jarak jauh dalam konteks pengajaran EFL. Oleh karena itu, tujuan dari penelitian ini adalah untuk mengetahui persepsi mahasiswa terhadap praktik pembelajaran jarak jauh di Universitas Muhammadiyah Gresik, khususnya pada kelas Words in Context sebagai mata kuliah utama pembelajaran Vocabulary (kosakata). Oleh karena itu, penelitian ini menggali beberapa aspek yang dibutuhkan dalam pelaksanaan praktik pembelajaran jarak jauh. Subjek penelitian ini adalah 34 mahasiswa semester satu jurusan pendidikan bahasa Inggris yang telah menerapkan praktik pembelajaran jarak jauh. Kuesioner digunakan sebagai instrumen penelitian untuk mengumpulkan data dari 34 responden yang telah dipilih. Selain itu, wawancara juga dilakukan untuk mengkonfirmasi hasil kuisioner. Setelah data terkumpul, kemudian dianalisis dengan menggunakan metode analisis kuantitatif dan kualitatif. Hasil penelitian menunjukkan bahwa siswa memiliki persepsi yang rata-rata terhadap pelaksanaan praktik pembelajaran jarak jauh, karena praktik pembelajaran jarak jauh memberikan keuntungan bagi proses pembelajaran mereka. Namun demikian, terdapat beberapa kendala seperti
\end{abstract}


partisipasi siswa, konektivitas internet, dan kejelasan materi yang perlu diperbaiki guna meningkatkan kualitas praktik pembelajaran jarak jauh.

Kata Kunci: Persepsi Siswa, Pembelajaran Jarak Jauh

\section{INTRODUCTION}

Distance learning practice is an essential option to assist and facilitate teaching and learning process in all education levels. It offers additional media for students to be in contact with peers and teachers outside the classroom. In addition, it also allows students to manage their own learning in the most appropriate way for each individual (Saddiqui, 2008). Moreover There are other numerous advantages of using distance learning platform that make it popular, for example it could be used to stimulate students' curiosity and maintain their interest, and as a result students become more active in their learning process instead of become passive observer or listener (Khalil, 2013). Distance learning platform could also increase problemsolving skill, nurture collaborative learning, provide flexible learning opportunities and increase productivity (Al-Harbi, 2014). Through distance learning practice too, students can have access to a wide range of learning resources and learning can occur anywhere, anytime, and there are no longer any geographical constraints for learning (Honey et al. 2000).

It is widely agreed that conducting distance learning effectively will be beneficial for all students especially those who live in remote areas and have difficulty accessing good quality education (Dyson et al. 2015). However, several problems are estimated to occur in the process as there are likely to be various challenges to be faced, including recurring issues such as poor connectivity infrastructure and underqualified human resources, as well as issues including choosing the suitable
Learning Management Systems. In addition, it is also a fact that in the most common distance learning practice, lecturers just deliver the content and material, then make the students learn it by themselves. Thus, there is no significant changes, instead it produces less collaboration among students and less students' participation in the class (Cope \& Ward, 2002).

Regardless of all those setbacks, distance learning platform is still considered as one of the most important media in modern education especially with the pandemic still hindering offline teaching and learning process (Huang et al. 2020). Therefore, lecturers and students are somewhat forced to use distance learning practice as in University of Muhammadiyah Gresik. This includes teaching and learning process in vocabulary class amidst all the reluctances given that most of the students are practically new to this learning system as well as new to the university life.

Because of that, the researcher would like to study three aspects which are related to the implementation of distance learning practice in vocabulary class. Those aspects contribute to the formulation of research questions of this study which are: (1) Do the students understand the vocabulary material if the teaching learning process is conducted using distance learning practice? (2) Does distance learning practice supports the students to study vocabulary better? (3) What is the students' opinion about distance learning practice that has been implemented in vocabulary class?

Based on those three aspects, the researcher was determined to find out the students' perception towards distance 
learning practice since students' perception is of high importance because it will provide clear understanding how distance learning practice should be implemented in a vocabulary class. Moreover, it can also give confirmation whether distance learning practice gives advantages based on the students' needs in their point of view or not. This is expected to contribute to addressing the existing acceptance and possible resistance by disclosing the factors uncovered by the study.

\section{METHOD}

This study used mixed method design or specifically qualitative survey design. The reason why survey method was employed in this research was because it is an efficient way of collecting information from respondents (Cohen, 2007). In addition, the study also used qualitative research design to complete the result of the survey. Prior to that, as initial research instrument of this study a questionnaire was developed.

The questionnaire consisted of three section; evaluation, memory, and impression. It was organized into those three categories since perception is seen as the outputs from evaluations, memories, and impressions that are acquired and shaped by humans' knowledge and experiences in social phenomenon (Marcrae and Baden Hausen, 2001).

Section 1 consisted of seven items aimed to obtain information about respondents' evaluation about implementing distance learning practice in vocabulary class. Section 2 contained seven items concerning respondents' memory based on their experiences in the process of distance learning practice. Section 3 consisted of seven items regarding to participants' impression toward distance learning practice.
All those three sections useed 5-points Likert scale, with the option of strongly agree, agree, unsure, disagree, and strongly disagree. The questionnaire was then given to 34 respondents of first semester students who had applied distance learning practice in vocabulary class. Furthermore, five students were chosen by purposive and snowball sampling for conducting interview in order to confirm and complete the result of the questionnaire.

After the data from both questionnaire and interview sections were collected, the researcher analyzed the data using two kinds of data analysis. Quantitative data were examined using two formulas with the intention of knowing the percentage of the students who fulfil the questionnaire and the mean score of each individual (Dornyei, 2003). As for qualitative data, coding, displaying, and concluding were employed to study the interview result.

\section{FINDING AND DISCUSSION}

\section{Finding}

The percentage of the respondents who gave participation in questionnaire was $100 \%$ respondents. It means that all respondents gave their participations to fulfil questionnaire. Here are the results of questionnaire section (Table 1).

Table 1: Summary of All Sections

\begin{tabular}{lccc} 
& Agree (\%) & Average (\%) & Disagree (\%) \\
\hline Evaluation & 44.9 & 52.1 & 2.94 \\
\hline Memory & 0 & 58.88 & 41.12 \\
\hline Impression & 23.55 & 67.63 & 8.8 \\
\hline Mean & 14.8 & 76.47 & 8.7
\end{tabular}

The first aspect is evaluation which is the basic level of perception. In this study, the researcher evaluated students' perception during process of teaching 
learning through distance learning practice from students answer in questionnaire. Then, the researcher did interview to the respondents to get data that were not gotten in questionnaire section. Here are the results of questionnaire section and the result of interview to complete the result of questionnaire (Table 2).

Table 2: Evaluation Section

\begin{tabular}{|c|c|c|c|c|c|}
\hline No & Statement & $\begin{array}{c}\text { Strongly } \\
\text { Agree } \\
(\%)\end{array}$ & $\begin{array}{c}\text { Agree } \\
(\%)\end{array}$ & $\begin{array}{c}\text { Unsure } \\
(\%)\end{array}$ & $\begin{array}{c}\text { Disagree } \\
(\%)\end{array}$ \\
\hline 1 & $\begin{array}{l}\text { The goal of } \\
\text { distance } \\
\text { learning } \\
\text { practice is in } \\
\text { line with the } \\
\text { teaching } \\
\text { learning } \\
\text { process }\end{array}$ & 0 & 14.79 & 50 & 35.21 \\
\hline 2 & $\begin{array}{l}\text { The purpose of } \\
\text { distance } \\
\text { learning } \\
\text { practice is in } \\
\text { line with the } \\
\text { competence of } \\
\text { students }\end{array}$ & 0 & 8.8 & 47.02 & 44.16 \\
\hline 3 & $\begin{array}{l}\text { The } \\
\text { implementation } \\
\text { of distance } \\
\text { learning } \\
\text { practice is in } \\
\text { line with the } \\
\text { students' need } \\
\text { in learning } \\
\text { process }\end{array}$ & 0 & 11.76 & 47.08 & 41.16 \\
\hline 4 & $\begin{array}{l}\text { Lecturer is } \\
\text { involved in } \\
\text { learning } \\
\text { process through } \\
\text { distance } \\
\text { learning } \\
\text { practice }\end{array}$ & 2.97 & 76.44 & 14.78 & 5.81 \\
\hline 5 & $\begin{array}{l}\text { Students are } \\
\text { involved in } \\
\text { learning } \\
\text { process through } \\
\text { distance } \\
\text { learning } \\
\text { practice }\end{array}$ & 2.91 & 52.91 & 29.44 & 14.74 \\
\hline 6 & $\begin{array}{l}\text { The material } \\
\text { that provided in } \\
\text { distance } \\
\text { learning } \\
\text { practice is in }\end{array}$ & 0 & 20.58 & 38.24 & 41.19 \\
\hline
\end{tabular}

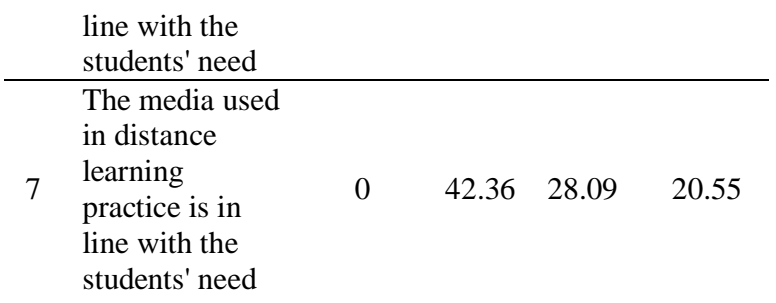

Based on average responses regarding the goal of distance learning practice and its suitability with students' competence, the students stated that the purpose of distance learning practice were to provide media and facilitation do to learning activity easily every time and everywhere which means it was appropriate with the learning process of vocabulary because the students need many meetings and it could happen in distance learning practice. The students also felt appropriate because they could get information and the example of material, but sometimes they needed more explanation to discuss it directly with lecturer, because they wanted to know the content of it clearly. If they knew the content of that information, they could write the part of thesis well. This result is indicated to item number 1 and 2.

The needs of students in the teaching learning process are about being able to do learning process easily and understand the material completely. Through distance learning practice the students could get material, submit their assignment, and get feedback from lecturer. It means that they could do that activity easily via distance learning practice. In other hand the students need more explanation and more meeting to discuss the information or material that they got from distance learning practice with their lecturer. This result showed the explanation from item number 3 and 6 .

Based on the result of 7 questions that indicate to the evaluation, there were 18 students $(52,1 \%)$ answered average which 
means that students think that the purpose of distance learning practice have appropriate in the learning activity such as the students could download material, get feedback, submit their assignment, and discuss the material easily. It is in coherence with the students need in learning process but they need more meeting or more explanation about the content of material in order for them to reach the competence of vocabulary

The next aspect is memory which is one of the most important ways to understand and analyze students' histories, their current action, and past experience. Memory is retaining information related to students' experience, usually for present and future purposes. In this study, the researcher wants to examine whether students memory about the past experience influence their decision to use distance learning again in learning process (Table 3 ).

Table 3: Memory Section

\begin{tabular}{|c|c|c|c|c|c|}
\hline No & Statement & $\begin{array}{c}\text { Agree } \\
(\%)\end{array}$ & $\begin{array}{c}\text { Unsure } \\
(\%)\end{array}$ & $\begin{array}{c}\text { Disagree } \\
(\%)\end{array}$ & $\begin{array}{c}\text { Strongly } \\
\text { disagree } \\
(\%)\end{array}$ \\
\hline $9 a$ & $\begin{array}{l}\text { Distance } \\
\text { learning } \\
\text { practice } \\
\text { becomes a } \\
\text { motivating } \\
\text { activity towards } \\
\text { the purpose of } \\
\text { learning. }\end{array}$ & 17.64 & 52.97 & 26.44 & 2.95 \\
\hline $9 b$ & $\begin{array}{l}\text { Distance } \\
\text { learning } \\
\text { practice gives } \\
\text { motivation for } \\
\text { students to get } \\
\text { vocabulary } \\
\text { material. }\end{array}$ & 17.64 & 52.95 & 29.41 & 0 \\
\hline $9 \mathrm{c}$ & $\begin{array}{l}\text { Distance } \\
\text { learning } \\
\text { practice } \\
\text { increases } \\
\text { motivation for } \\
\text { students to be } \\
\text { competence in } \\
\text { vocabulary } \\
\text { subject }\end{array}$ & 26.48 & 41.15 & 32.37 & 0 \\
\hline
\end{tabular}

\begin{tabular}{|c|c|c|c|c|c|}
\hline 10 & $\begin{array}{l}\text { Distance } \\
\text { learning } \\
\text { practice } \\
\text { provides } \\
\text { conducive } \\
\text { learning } \\
\text { environment }\end{array}$ & 14.76 & 23.51 & 61.73 & 0 \\
\hline 11 & $\begin{array}{l}\text { Distance } \\
\text { learning } \\
\text { practice help } \\
\text { students to } \\
\text { reach top result } \\
\text { of the study } \\
\text { rather than } \\
\text { offline learning } \\
\text { process in class }\end{array}$ & 2.95 & 32.32 & 58.88 & 5.84 \\
\hline 12 & $\begin{array}{l}\text { Students have } \\
\text { various options } \\
\text { for studying } \\
\text { through } \\
\text { distance } \\
\text { learning } \\
\text { practice }\end{array}$ & 42.31 & 29.44 & 28.25 & 0 \\
\hline 13 & $\begin{array}{l}\text { Distance } \\
\text { learning } \\
\text { practice could } \\
\text { make learning } \\
\text { process more } \\
\text { effective }\end{array}$ & 14.75 & 32.34 & 52.91 & 0 \\
\hline 14 & $\begin{array}{l}\text { Students will } \\
\text { continue } \\
\text { distance } \\
\text { learning } \\
\text { practice in } \\
\text { other learning } \\
\text { process based } \\
\text { on students' } \\
\text { experience }\end{array}$ & 8.4 & 58.8 & 29.8 & 2.94 \\
\hline
\end{tabular}

Based on the result of interview, the students got advantage from distance learning practice. They could download material that was provided by lecturer, submitted their assignments easily through distance learning practice, discussed one of students' assignment and got feedback from lecturer, but they did not understand about the content of their discussion through distance learning practice. They were also difficult to understand the material and feedback that had been downloaded by them. They needed more explanation of that material from lecturer, 
and it could not be done in distance learning practice. In vocabulary subject last year, many materials that had to be explained more, like how to determine thesis title, and how to write background of the study. The students needed that explanation in class directly or face to face with lecturer. This result indicated to the result of questionnaire for number $9 a, 9 b$, and $9 \mathrm{c}$.

The students were interested to use distance learning practice again if some aspects and problems in the implementation of distance learning practice last semester which had already been mentioned before were completed. Those some aspects and some problems were students' participation, internet networking, clear material, and students' comprehension about the content of material that was provided in distance learning practice. This result gives explanation for the result of questionnaire number 14.

Some students also wanted to use distance learning practice again, but they hoped that the percentage of learning in class had more percentage than distance learning practice because they were afraid that they did not understand about the content of learning activity through distance learning practice. It means that the lecturer needed to explain more the material that could not be understood by students in distance learning practice, in order to students understand about the material. Distance learning practice wants to be used by lecturer and students when they don't have much time to study in class. Distance learning will be a media that help lecturer and students when they have limited time to do learning activity in the class.

Based on the result of 8 questions that indicate to the memory, there were 20 students $(58,82 \%)$ had average answer.
Most of students had answer average. It means that in the implementation of distance learning practice they think that distance learning practice gives some advantages to learning process such as getting material, but they cannot understand that material well. They want to use distance learning practice again in other learning process if problems in the implementation of distance learning are solved.

The third aspect is impression which is the overall effect of implementing distance learning practice in vocabulary class. Impression refers to the process in which individuals attempt to influence the opinions or perceptions. Here, the researcher examines the impressions of students about implementing distance learning in learning process (Table 4).

Table 4: Impression Section

\begin{tabular}{|c|c|c|c|c|c|}
\hline No & Statement & $\begin{array}{c}\text { Agree } \\
(\%)\end{array}$ & $\begin{array}{c}\text { Unsure } \\
(\%)\end{array}$ & $\begin{array}{c}\text { Disagree } \\
(\%)\end{array}$ & $\begin{array}{c}\text { Strongly } \\
\text { Disagree } \\
(\%)\end{array}$ \\
\hline 15 & $\begin{array}{l}\text { Distance } \\
\text { learning practice } \\
\text { helps students in } \\
\text { learning process }\end{array}$ & 20.59 & 41.18 & 35.29 & 2.94 \\
\hline 16 & $\begin{array}{l}\text { Some features } \\
\text { that are } \\
\text { provided in } \\
\text { distance } \\
\text { learning practice } \\
\text { could make } \\
\text { learning process } \\
\text { easier }\end{array}$ & 23.53 & 38.24 & 38.24 & 0 \\
\hline 17 & $\begin{array}{l}\text { Distance } \\
\text { learning practice } \\
\text { helps students to } \\
\text { get vocabulary } \\
\text { material faster }\end{array}$ & 29.41 & 35.29 & 32.35 & 2.94 \\
\hline 18 & $\begin{array}{l}\text { Discussion } \\
\text { forum in } \\
\text { distance } \\
\text { learning practice } \\
\text { could improve } \\
\text { students' } \\
\text { motivation to } \\
\text { study more }\end{array}$ & 14.71 & 41.18 & 38.24 & 5.88 \\
\hline
\end{tabular}




\begin{tabular}{|c|c|c|c|c|c|}
\hline 19 & $\begin{array}{l}\text { Distance } \\
\text { learning practice } \\
\text { helps students to } \\
\text { get feedback of } \\
\text { their assignment } \\
\text { easily }\end{array}$ & 28.65 & 48.24 & 14.12 & 0 \\
\hline 20 & $\begin{array}{l}\text { Information that } \\
\text { are provided in } \\
\text { distance } \\
\text { learning practice } \\
\text { could make } \\
\text { students become } \\
\text { interested to } \\
\text { study }\end{array}$ & 11.76 & 67.65 & 17.65 & 2.94 \\
\hline 21 & $\begin{array}{l}\text { Students use } \\
\text { distance } \\
\text { learning practice } \\
\text { maximally }\end{array}$ & 11.76 & 52.94 & 35.29 & 0 \\
\hline
\end{tabular}

Based on interview result, most of students thought that distance learning practice was useful to support learning activity, because there were some tools in distance learning practice that could be used by lecturer and students. Those tools were online discussion forum, submitting assignment, and getting output material which had been provided by lecturer through distance learning practice.

As we knew that the purpose of distance learning practice was giving media or facilitation to the subject of learning, so distance learning practice provided some tools that had already mentioned above. Those tools were used by students to do learning activity easily. The students also found some aspects and some problems that had to be attention in the implementation of distance learning practice in order to distance learning practice could be implemented maximally. This result to complete the result of questionnaire for item number 15, 16 and 17 , here are the result interviews to support statement above.

Related to the explanation above, the student thinks that there were some aspects that had to be attention in the implementation of distance learning practice. First, students' participation was needed in learning process, because they were subject of learning, so all the students had to give their participations there. The second important aspect in the implementation of distance learning practice was internet networking. Internet networking was important to connect in distance learning practice, without internet the students could not use distance learning practice. The last aspect was clear material. The lecturer shall provide appropriate material or clear material in distance learning practice because students needed clear material in their learning process in vocabulary class in order to students could understand material well.

In the implementation of distance learning practice last semester, the students think that distance learning practice was the most effective if they did not have problem to implement distance learning practice because they could study everywhere in different place and get interesting information but the students felt that internet networking was a problem in distance learning practice. Internet networking was the important aspect to use distance learning practice, because it was distance learning practice (electronic learning), so all the activity in distance learning practice shall use internet connection. Actually the students could discuss and do learning activity everywhere and every time but most of students did not have good internet connection everywhere especially in their home. It could make an obstacle to implement distance learning practice because if students did not connect to internet, they could not open their account in distance learning and they could not do learning activity through distance learning practice. This result was indicated to item of questionnaire number 18 and 20.

Based on the result of 7 questions that indicate to the impression, there were 23 
students (67, 65\%) had average answer. Most of students answered average. It means that they think distance learning practice was useful in vocabulary class but there are some problems and aspects that have to be attention to the implementation of distance learning practice, these aspects and problems are students' participation, internet networking, clear material, and students' comprehension about the material.

\section{Discussion}

Based on the finding in questionnaire, the researcher found that students had different perception toward implementation distance learning practice. Based on the answer of the questionnaire most of the students had average perception. It means that they think that distance learning practice is important to implement in learning activity yet they feel that this kind of learning practice is not as effective as the traditional classroom activities. It is because distance learning practice gives some advantages to learning process but there are some aspects or some problems that had to be solved in order for the learning practice to run well. This result is not consistent with the previous study (Tasir et. al., 2013) that stated that the students had positive perception towards distance learning practice.

In interview result, the students' evaluation about distance learning practice, they think that actually distance learning practice has good advantages to the learning activity. Those advantages are they can discuss everywhere, they are able to download material, and they can connect with the lecturer and students in difference place. This result corresponds with the previous study (Cakrawati, 2017) that stated distance learning practice forum is for knowledge sharing and distance learning practice space is for collaboration, interactivity and open space for instructional discussion when they were taught using Quipper and Edmodo. It means that distance learning practice is appropriate to students' need in learning process, but they need more explanation and more meeting with lecturer to discuss material directly to reach competence in vocabulary subject.

Students' memories toward distance learning practice in vocabulary class is the students feel advantages of distance learning practice, they can download material and feedback from distance learning practice easily, they also can get feedback from lecturer but the problems are they do not understand about that feedback. They need more explanation because it is vocabulary subject, so students have to know how to write thesis well and it need more explanation directly. They cannot understand material well by reading and written text from distance learning practice. This result is not consistent with the previous study (Rojabi, 2020)) stated that students agreed that they have more enjoyable environment to study and communicate in distance learning practice especially when using Microsoft Teams.

Second problem is internet networking, in the implementation of distance learning practice has to connect to internet. If some of the students don't connect to internet, learning activity in distance learning practice can't run well. This result is consistent the previous study (Tagoe, 2012) that stated that actually distance learning practice was going to enhance teaching and learning process, but there was problem in connectivity. In vocabulary subject, the lecturer ever did discussion forum in distance learning for students. In that forum, the students are asked to give comment, question and opinion to others 
students' thesis title, but in fact, just a few students who online to that forum because some of students don't have good internet connection.

Students' impressions toward distance learning practice in vocabulary subject is they find some aspects that have to be attention to the implementation of distance learning practice. First, students' participation in the implementation of distance learning practice because they are subject of learning, so all the students have to participate in online course. If students are not interested to use distance learning practice, it means that there are no participate there; it gives impact to the learning activity. Learning activity can't run well and distance learning practice can't be implemented maximally.

Second, good internet networking is important to make students have stronger sense of connection in distance learning practice since the learning activities in this study were conducted both by synchronous meetings and asynchronous discussions (Yamagata-Lynch, 2014). If some students do not have good internet networking, they can't join in online course and that is an obstacle to use distance learning practice in learning activity. So, the lecturer and students should have good internet networking everywhere. This result is consistent the previous study (Tagoe, 2012) that stated that actually distance learning practice was going to enhance teaching and learning process, but there was problem in connectivity. Last, the lecturer has to provide appropriate material and clear material in distance learning practice in order for students to comprehend the material easily. If the aspects that have been mentioned before are solved, they are interested to use distance learning practice as long as it will not exceed the frequency of traditional classroom meetings.
Moreover, the students want to use distance learning practice when they have limited time or limited condition to study in class. This result matches with previous researcher (Tagoe, 2012). The students from that research stated disagreed that fully online courses should replace all face to face teaching at undergraduate level and there should be some combination of online and face to face teaching.

In summary, the students think that distance learning practice gives advantages to the learning and it is appropriate with students need in learning process, but they found some problems in the implementation of distance learning practice last semester. The students want to use distance learning practice again in the next subject if some aspects and problems that are needed to implement distance learning practice are handled thoroughly.

\section{CONCLUSION}

In conclusion, most students have average perception towards distance learning practice, it means that the students think that distance learning practice could give them various advantages to do learning activity such as submitting assignment, getting feedback, downloading material and having discussion in online forum. It is in line with the students' needs in learning process. However, in the implementation of distance learning practice in vocabulary class, they experience problems that became obstacles when conducting distance learning practice. Those problems are the students could not understand well about the vocabulary material or feedback that provided in distance learning practice. They needed more explanation about the material directly. In addition, some of the students do not have good internet network. Therefore, the students want to use distance 
learning practice again in the next subject if some factors and some problems that are needed to implement distance learning practice are improved. Those factors are students' participation, students' knowledge to implement distance learning practice, good internet connectivity, and appropriate material that is provided in distance learning practice. Despite that, the students do not want to use distance learning practice fully in their learning activity.

Based on the finding of the study, the researcher would like to give some suggestions. The researcher hopes that the university can improve some aspects that are needed in the implementation of distance learning practice in order to be able to be used by lecturers and students maximally, such as good internet connectivity, as well as improving the features in distance learning practice to be a better media and provide facilitation to support learning activity. Additionally, the university is hoped to implement distance learning practice in all the subjects in every faculty in order to reach successful results of teaching learning process. As for the lecturers, the researcher hopes that the lecturers could provide more interaction when conducting distance learning practice and give motivation for the students to try exploring it individually.

\section{REFERENCES}

Al Harbi, Hanaa, Eid. (2014). Towards Successful Implementation Of distance learning platform In Education. WEI International Academic Conference Proceedings.

Cakrawati, L. M. (2017). Students' Perceptions on the use of Online Learning Platforms in EFL Classroom. ELT Tech: Journal of
English Language Teaching and Technology, 1(1), 22-30.

Cohen, Louis and Manion, Lawrence and Morrison, Keith. (2007). Research Methods in Education. London: Routledge.

Cope, C., \& Ward, P. (2002). Integrating learning technology into classrooms: The importance of teachers' perceptions. Journal of Educational Technology \& Society, 5(1), 67-74.

Dorney, Zoltan. (2003). Questionnaires in second language research. University of Nottingham: London.

Dyson, B., Vickers, K., Turtle, J., Cowan, S., \& Tassone, A. (2015). Evaluating the use of Facebook to increase student engagement and understanding in lecture-based classes. Higher Education, 69(2), 303-313.

Khalil, S. M. (2013). From resistance to acceptance and use of technology in academia. Open Praxis. 5(2) 151-163

Macrae, N. and Bodenhausen, G. (2001). Social cognition: categorical person perception. The British Psychological society. 239-255.

Honey, M., Culp, K. M. \& Carrigg, F. (2000). Perspectives on technology and education research: Lessons from the past and present. Journal of Educational Research, 23(1), 5-14

Huang, R.H., Liu, D.J., Tlili, A., Yang, J.F., Wang, H.H., et al. (2020). Handbook on Facilitating Flexible Learning during Educational Disruption: The Chinese Experience in Maintaining Undisrupted Learning in COVID-19 Outbreak. Beijing: Smart Learning Institute of Beijing Normal University.

Rojabi, A. R. (2020). Exploring EFL Students' Perception of Online Learning via Microsoft Teams: University Level in Indonesia. English Language 
Teaching Educational Journal,3(2), 163-173.

Saddiqui, M. H. (2008). Distance learning technologies in education. New Delhi: A. P. H. Publishing Corporation.

Tasir, Z. Al - Dheleai, Y. Harun, J. Shukor, N. (2013). Students' Perception towards the Use of Social Networking as an elearning Platform. Universiti Teknologi Malaysia.

Tagoe, Michael. (2012). Students' perceptions on incorporating distance learning practice into teaching and learning at the University of Ghana. International Journal of Education and Development using Information and Communication Technology (IJED distance learning platform).

Yamagata-Lynch, L. C. (2014). Blending online asynchronous and synchronous learning. International Review of Research in Open and Distributed Learning, 15(2), 189-212. 